\title{
Environmental Measurements at the Savannah River Site with Underwater Gamma Detectors (U)
}

by

W. G. Winn

Westinghouse Savannah River Company

Savannah River Site

Aiken, South Carolina 29808

A document prepared for PRESENTATION AT THE METHODS AND APPLICATIONS OF RADIOANALYTICAL CHEMISTRY III MEETING AND FOR PUBLICATION IN THE JOURNAL OF RADIOANALYTICAL AND NUCLEAR CHEMISTRY at Kailua-Kona, Hawaii from 04/10/94 - 04/16/94.

\section{DOE Contract No. DE-AC09-89SR18035}

This paper was prepared in connection with work done under the above contract number with the U.S. Department of Energy. By acceptance of this paper, the publisher and/or recipient acknowledges the U.S. Government's right to retain a nonexclusive, royalty-free license in and to any copyright covering this paper, along with the right to reproduce and to authorize others to reproduce all or part of the copyrighted paper. 


\section{DISCLAMMER}

Portions of this document may be illegible in electronic image products. Images are produced from the best available original document. 


\section{DISCLATMER}

This report was prepared as an account of work sponsored by an agency of the United States Government. Neither the United States Government nor any agency thereof, nor any of their employees, makes any warranty, express or implied, or assumes any legal liability or responsibility for the accuracy, completeness, or usefulness of any information, apparatus, product, or process disclosed, or represents that its use would not infringe privately owned rights. Reference herein to any specific commercial product, process, or service by trade name, trademark, manufacturer, or otherwise does not necessarily constitute or imply its endorsement, recommendation, or favoring by the United States Government or any agency thereof. The views and opinions of authors expressed herein do not necessarily state or refiect those of the United States Government or any agency thereof.

This report has been reproduced directly from the best available copy.

Available to DOE and DOE contractors from the Office of Scientific and Technical Information, P.O. Box 62, Oak Ridge, TN 37831; prices available from (615) 576-8401:

Available to the public from the National Technical Information Service, U.S. Department of Commerce, 5285 Port Royal Road, Springfield, VA 22161. 


\title{
ENVIRONMENTAL MEASUREMENTS AT THE SAVANNAH RIVER SITE WITH UNDERWATER GAMMA DETECTORS
}

\author{
W.G. WINN \\ Westinghouse Savannah River Company \\ Aiken, South Carolina 29808
}

\begin{abstract}
Underwater $\mathrm{NaI}(\mathrm{Tl})$ and HPGe detectors are used in the environmental measurements programs at the Savannath River Site (SRS). A $22.9 \mathrm{~cm} \times 10.2 \mathrm{~cm} \mathrm{NaI(TI)} \mathrm{detector} \mathrm{on} \mathrm{the} \mathrm{Savannah} \mathrm{River}$ continuously monitors effluent releases from both SRS (DOE) and Plant Vogtle (Georgia Power). Correlations with known releases indicate a sensitivity of $4 \mathrm{mBq} / \mathrm{for}{ }^{58} \mathrm{Co}$ with $1500 \mathrm{~min}$ spectra; such levels are well below those of hazardous or legal concern. A $30 \%$-efficient HPGe detector has appraised radionuclides in SRS cooling pond sediments; the dominant gamma-emitting radionuclide detected was ${ }^{137} \mathrm{Cs}$, at levels ranging up to $2.0 \mathrm{MBq} / \mathrm{m}^{2}$. The pond activities were adequately quantified by 1 min counts with the HPGe detector; resulting contour maps of sediment ${ }^{137} \mathrm{Cs}$ provided guidance for partially draining the ponds for dam repairs.
\end{abstract}

The monitoring of waterways connected with the Savannah River Site (Fig. 1) has been an ongoing effort since the beginning of operations in the early 1950's. The Savannah River itself has been a source of cooling water for the five SRS production reactors, now shut down. The discharged water returned to the river has been closely monitored since startup. SRS operates two separations facilities that also have potential for releases to the river. Directly across the river from SRS, Plant Vogtle of Georgia Power initiated nuclear power operations in 1987, and their releases have also been monitored since startup. During early operations at SRS, ponds were developed to cool the reactor discharges prior to release to the river. The ponds have also contained inadvertent releases of radionuclides.

Following development in the early 1970 's, underwater gamma detectors have monitored the Savannah River and SRS ponds. Since 1987, an underwater NaI detector has continuously monitored the river downstream of the facilities to help distinguish SRS and Vogtle effluents. Beginning in 1991, an underwater HPGe detector was used to map radionuclides in pond sediments. Due to a need for dam repairs, Par Pond, the largest SRS pond, was lowered by $5.8 \mathrm{~m}$. Pond $\mathrm{C}$, an adjacent feed pond, was lowered $1.8 \mathrm{~m}$ to reduce the differential pressure along a causeway separating the ponds. Sediment to be exposed by these lowerings contained radionuclides released from two SRS reactors about 30 years earlier ${ }^{1}$.

\section{Equipment}

\section{Experimental}

Both the underwater NaI and HPGe detectors are deployed from pontoon craft using deck winches and trap doors. The NaI detector utilizes a pontoon platform permanently moored in the Savannah River at US Highway 301 Bridge, which is about $50 \mathrm{~km}$ downstream of both SRS and Plant Vogtle. It has a temperature-controlled weatherproof cabin that receives line power from shore, allowing unattended counting operations over extended periods. The HPGe detector is deployed from a pontoon boat, which has no cabin or permanent power source; thus, favorable weather conditions are required, and power is derived from batteries and/or a $5 \mathrm{kVA}$ gasoline generator. Operations for taking measurements with the HPGe are usually conducted within a normal 8 -hr work day.

The underwater NaI detector consists of a $22.9 \mathrm{~cm}$ diameter by $10.2 \mathrm{~cm}$ long NaI crystal, four photomultiplier tubes, and a high-voltage/preamp unit, all within a waterproof stainless steel 
housing. The detector views its surroundings through a thin stainless steel hemisphere, and is normally $3 \mathrm{~m}$ below the water surface but well above the river bottom. The detector receives power via a waterproof cable connected to a 25 VDC supply; the same cable uses an AC coupling to transmit the detector pulses to an amplifier. The amplified pulses are then input to a multichannel analyzer (portable COMPAQ computer with ACETM card). Spectra are stored on floppy disk in sequenced 24-hr periods, and then analyzed with the GRABNAI code?

The underwater HPGe detector has $30 \%$ efficiency, relative to standard comparison with a 7.6 $\mathrm{cm} \times 7.6 \mathrm{~cm} \mathrm{NaI}$ detector. The detector assembly (dewar and probe) is situated in a screen housing, which protects the detector from shocks and defines a detector-to-sediment distance of $12.7 \mathrm{~cm}$. A waterproof tube vents the liquid nitrogen vapors, and another waterproof tube passes preamp power, HV, and signal cables to the spectrometry electronics on the deck. The spectrometry electronics has operated in two modes: initially, standard NIM electronics powered the detector and amplified the signals for processing by a portable COMPAQ computer with an ACETM card; later, a more compact NOMADTM unit replaced the NIM electronics, and a smaller Dolch computer was used. A typical gamma spectrum was saved on disk after counting one minute. Because only ${ }^{137} \mathrm{Cs}$ was usually detected, ROI-spectral analysis was normally sufficient, although some analyses used the GRABGAM code? 2 .

While the underwater NaI detector had a single well-characterized location, the HPGe mapping studies involved numerous locations, which required coordinate data for deducing the radionuclide contours of the pond sediment. Various methods were used to obtain site coordinates. A Magellan TM Global Positioning System unit provided the best information, which was augmented by correlating mapped contour depths with depth gauge readings at the sites.

\section{Calibrations}

Calibrations were deduced for both the underwater NaI and HPGe detectors. As the NaI detector primarily signals releases that are noticeably above background, only a rough calibration was estimated. The HPGe measurements were to appraise historical information about the releases to the ponds, while providing guidelines for restricting operations where sediment later became exposed. Thus, a more refined calibration was developed for the underwater HPGe detector.

The underwater $\mathrm{NaI}$ detector was calibrated for ${ }^{58} \mathrm{Co}$, which has been the dominant radionuclide released by Plant Vogtle. (SRS radionuclide concentrations are dominated by ${ }^{137} \mathrm{Cs}$, which are now low and slowly decaying because of significantly reduced nuclear releases from SRS activities in recent years). Ultra-low-level gamma spectrometry of water filter samples collected near the $\mathrm{NaI}$ detector provided a calibration for the detector 3,4 . Comparing the 24-hr underwater $\mathrm{NaI}$ spectra to these measurements yielded a detection limit of $4 \mathrm{mBq} / 1$ for $811 \mathrm{keV}$ gammas of ${ }^{58} \mathrm{Co}$. Reasonable efficiency estimates indicate that the sensitivity should be worse by at least a factor of five; however, evidence suggests that river particulates continuously collect and wash off the detector surface, so that much of the activity is concentrated and counted close to the detector ${ }^{3}$.

The underwater HPGe detector was calibrated for ${ }^{137} \mathrm{Cs}$, the dominant radionuclide detected in the pond sediment. (The only other radionuclide detected was ${ }^{60} \mathrm{Co}$, with activity of only $\sim 1 \%$ that of $\left.{ }^{137} \mathrm{Cs}\right) .{ }^{4}$ The ${ }^{137} \mathrm{Cs}$ calibration was deduced by modeling the efficiency for its $662 \mathrm{keV}$ gammas relative to that of a point source centered below the detector at the sediment distance. The calculations used data from segmented sediment cores to model the density and ${ }^{137} \mathrm{Cs}$ profiles as a function of depth into the sediment. 5,6 The water above the sediment was also modeled. These data allowed calculation of the attenuated efficiencies of points within the sediment, which were averaged relative to the ${ }^{137} \mathrm{Cs}$ profile. Direct measurements with a ${ }^{137} \mathrm{Cs}$ point source provided normalization of the absolute efficiency for the sediment geometry, yielding a calibration of 630 $\mathrm{Bq} / \mathrm{m}^{2} / \mathrm{cpm}$. An alternative calibration in units of $\mathrm{Bq} / \mathrm{kg} / \mathrm{cpm}$ was developed for estimating occupational doses for resuspension and plowing; however, this calibration is functionally dependent on the depth of sediment contributing to the dose. 5 


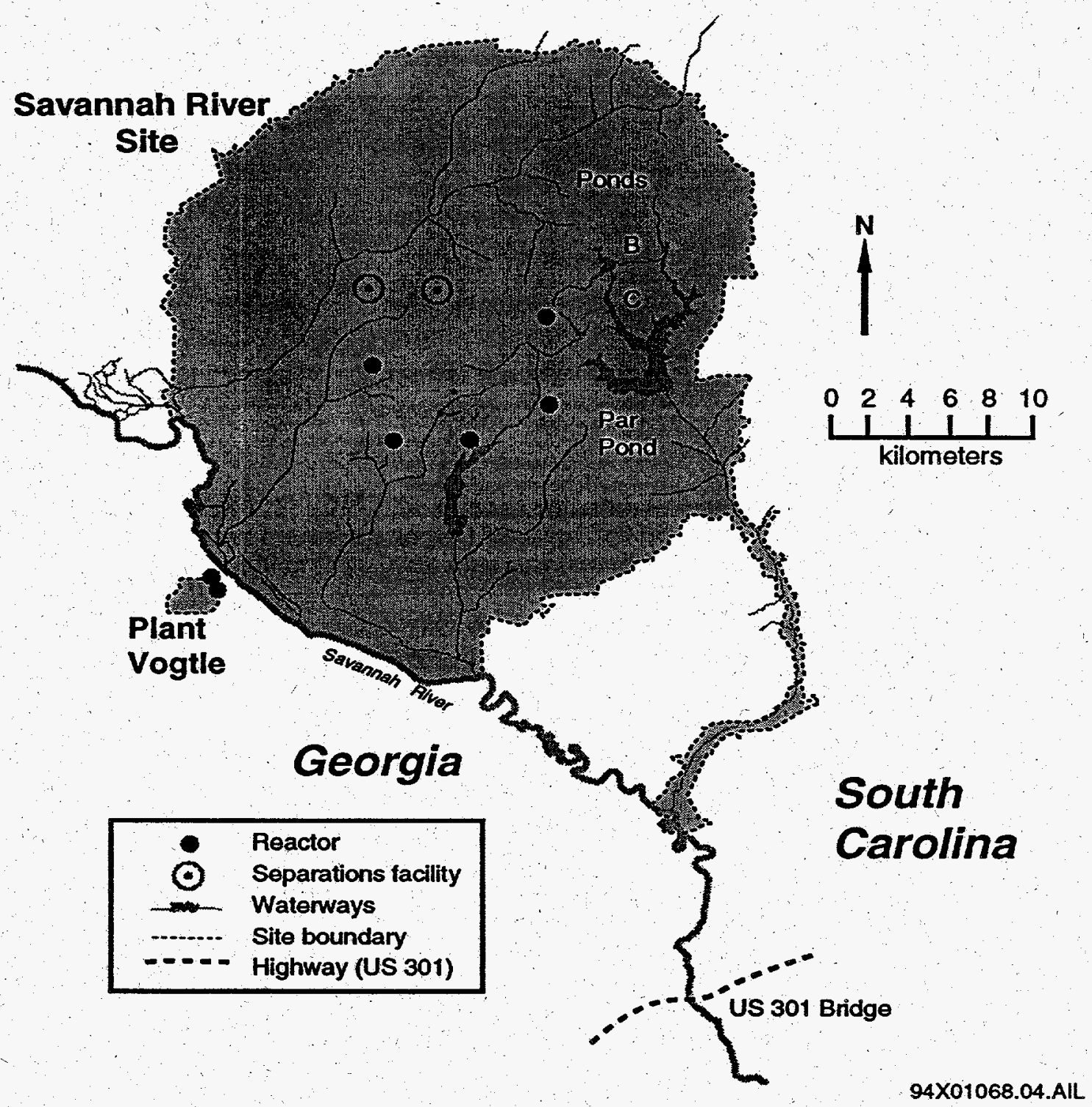

Fig 1. Area associated with the Savannah River Site 


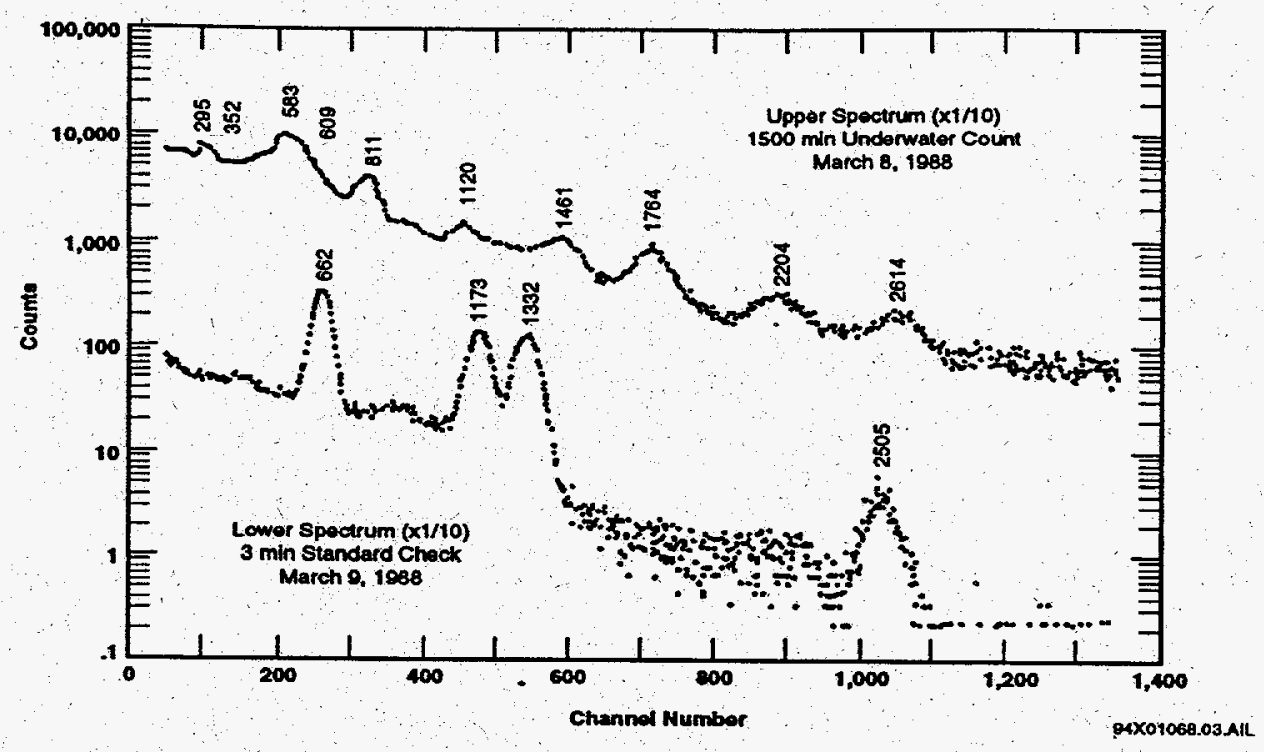

Fig 2. Underwater $\mathrm{Nal}$ detector spectra with $58 \mathrm{Co}(811 \mathrm{keV}$ alone distinguished fromthe natural background (upper spectrum) and $137 \mathrm{Cs}(662 \mathrm{keV})$ and ${ }^{60} \mathrm{Co}(1173,1332$, and the sum $2505 \mathrm{keV}$ ) calibrations (lower spectrum)

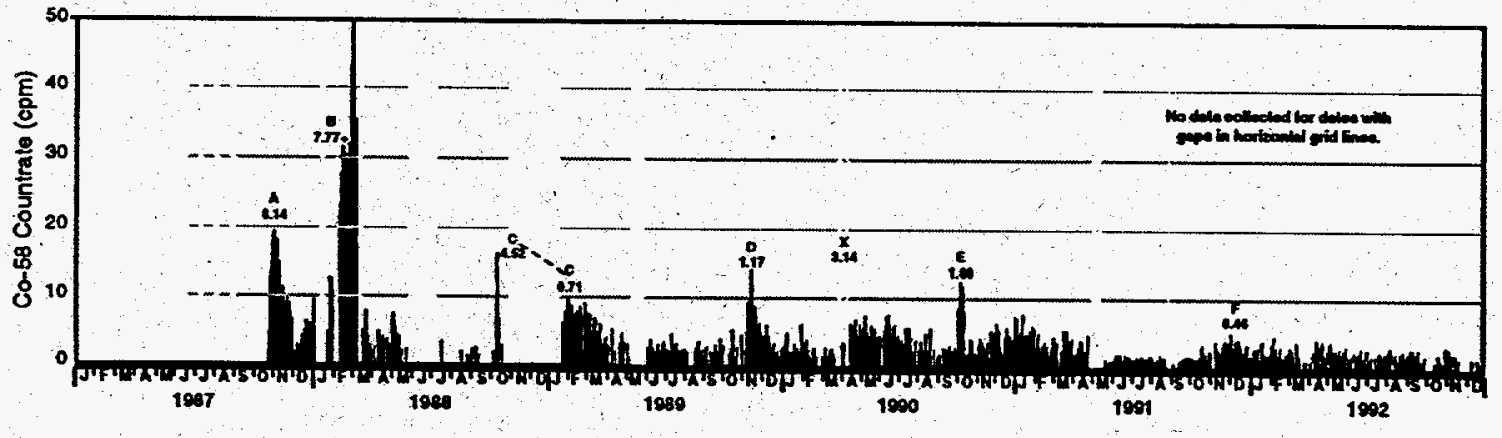

94X01068.07.AlL

Fig 3. Underwater $\mathrm{Nal}$ detector ${ }^{58} \mathrm{Co}$ countrate during 1987-1992 with notable releases identified by ID (letter) and released ${ }^{58} \mathrm{Co}$ GBq (number) as referenced in Table 1 


\section{Results}

Underwater NaI spectra (Fig. 2) clearly illustrate ${ }^{58} \mathrm{Co}$ detection by its $811 \mathrm{keV}$ gammas. Threedimensional time plots of $\mathrm{NaI}$ spectra have not distinguished other man-made radionuclides as readily ${ }^{3}$. Although some ${ }^{137} \mathrm{Cs}$ is present from SRS sources, it is masked within the multiplet peak that contains gammas of $583 \mathrm{keV}\left({ }^{208} \mathrm{Tl}\right)$ and $609 \mathrm{keV}\left({ }^{214} \mathrm{Bi}\right)$. During 1987-1992, the $811 \mathrm{keV}$ count rate of ${ }^{58} \mathrm{Co}$ correlated quite well with notable releases reported by Plant Vogtle (Fig. 3 ).

An example underwater HPGe spectrum (Fig. 4) includes both ${ }^{60} \mathrm{Co}$ and ${ }^{137} \mathrm{Cs}$. The spectrum illustrates that ${ }^{137} \mathrm{Cs}$ is the dominant gamma-emitting radionuclide in the pond sediment. In contrast to the $\mathrm{NaI}$ spectra, the absence of other gammas shows that ${ }^{60} \mathrm{Co}$ and ${ }^{137} \mathrm{Cs}$ activities are significantly larger than sediment natural background. Contour plots of Par Pond and Pond C (Fig. 5) range in ${ }^{137} \mathrm{Cs}$ activity from 0.0 to $2.0 \mathrm{MBq} / \mathrm{m}^{2}$. The Par Pond contours incorporate 213 measurements, and Pond $C$ uses 101; however, Pond $C$ being smaller has a significantly greater density of measurements. The Par Pond study benefited from earlier measurements with an underwater G-M counter; 5 thus, a priori knowledge guided selection of a smaller number of sites.

\section{Discussion}

The underwater $\mathrm{NaI}$ detector has tracked Plant Vogtle releases over a 6 year period quite well (Fig. 3). The releases correlate with Vogtle data ${ }^{3}$ of Table 1, which shows the dominance of ${ }^{58} \mathrm{Co}$. The results also show that release magnitudes have decreased over the years; this is due to Vogtle

Table 1

Notable Vogtle effluent releases during 1987-92 along with identifications (IDs) for correlation with ${ }^{58} \mathrm{Co}$ monitored with the underwater $\mathrm{NaI}$ detector (Fig. 3)

Vogtle Release Measurements, GBq

\begin{tabular}{|c|c|c|c|c|c|c|c|}
\hline ID & Date & ${ }^{51} \mathrm{Cr}$ & ${ }^{54} \mathrm{Mn}$ & ${ }^{58} \mathrm{Co}$ & ${ }^{9} \mathrm{Fe}$ & $95_{\mathrm{Nb}}$ & $\mathrm{NaI}$ comments \\
\hline$A$ & Oct 87 & 2.28 & 0.08 & 8.14 & 0.10 & 0.20 & First possible \\
\hline B & $\begin{array}{l}\mathrm{Feb} / 88 \\
\mathrm{Mar} / 88\end{array}$ & $\begin{array}{l}2.79 \\
1.15\end{array}$ & $\begin{array}{l}0.26 \\
0.14\end{array}$ & $\begin{array}{l}7.77 \\
4.51\end{array}$ & $\begin{array}{l}0.21 \\
0.09\end{array}$ & $\begin{array}{l}0.23 \\
0.12\end{array}$ & $\begin{array}{l}\text { Some effect of } \\
\text { Jan/88 release }\end{array}$ \\
\hline C & $\begin{array}{l}\text { Oct/88 } \\
\text { Feb/89 }\end{array}$ & $\begin{array}{l}1.93 \\
0.07\end{array}$ & $\begin{array}{l}0.17 \\
0.10\end{array}$ & $\begin{array}{l}4.52 \\
0.71\end{array}$ & $\begin{array}{l}0.42 \\
0.04\end{array}$ & $\begin{array}{l}0.10 \\
0.03\end{array}$ & $\begin{array}{l}\text { Out of service } \\
\text { Nov/88-Jan/89 }\end{array}$ \\
\hline D & Nov/89 & $:$ & 0.01 & 1.17 & 0.01 & 0.01 & Background up \\
\hline $\mathbf{x}$ & $\mathrm{Mar} / 90$ & 1.28 & 0.06 & 3.14 & 0.04 & 0.04 & Disk failure ${ }^{*}$ \\
\hline$E$ & Oct $/ 90$ & 0.27 & 0.02 & 1.89 & 0.02 & 0.01 & Background up \\
\hline $\mathbf{F}$ & Dec/91 & 0.11 & 0.01 & 0.46 & 0.01 & 0.03 & Lowest ${ }^{58} \mathrm{Co}$ \\
\hline
\end{tabular}

${ }^{*}$ Marginal data (Fig. 3) imply NaI-detected ${ }^{58} \mathrm{Co}$ is low relative to the Vogtle release; however, water filters near the detector and Vogtle outfall also indicated low ${ }^{58} \mathrm{Co}$, suggesting depletion in transport. 


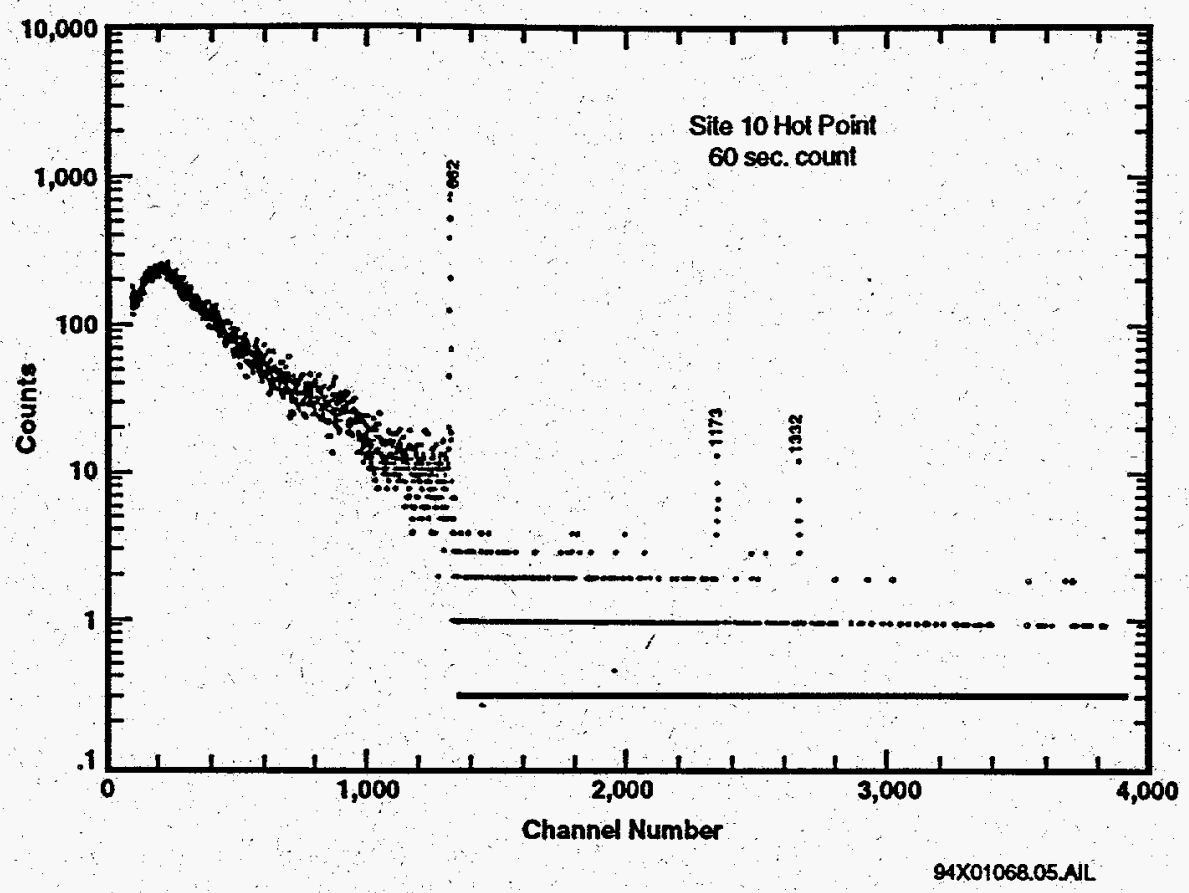

Fig 4. Underwater HPGe detector spectrum from Par Pond showing detection of ${ }^{137} \mathrm{Cs}(662 \mathrm{keV})$ and ${ }^{60} \mathrm{Co}(1173$ and $1332 \mathrm{keV})$

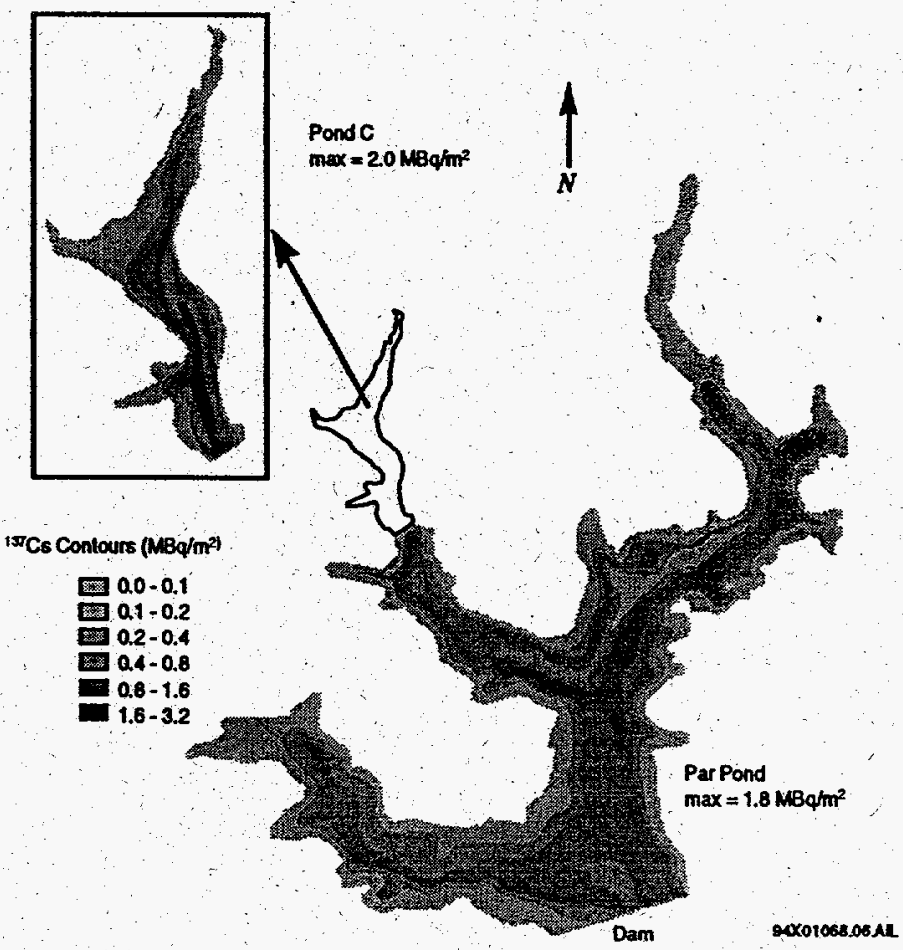

Fig 5. Par Pond and Pond C Contours for ${ }^{137} \mathrm{Cs}$ Activity 
improvements in pretreating the discharges. Marginal NaI data for a single release (ID $=\mathrm{X}$ ) implied too little ${ }^{58} \mathrm{Co}$ for reliable detection; low ${ }^{58} \mathrm{Co}$ was also detected in corresponding water filter samples, suggesting that an interim pretreatment method used only for this release caused ${ }^{58}$ Co depletion in transport. Overall, Plant Vogtle discharges have complied with regulatory requirements; thus, the underwater $\mathrm{NaI}$ has a demonstrated capability for detecting abnormal trends well before the onset of safety and legal concerns.

The underwater HPGe measurements were found to be consistent with other data concerning the ponds ${ }^{5,7}$ Pond inventories of ${ }^{137} \mathrm{Cs}$ have been estimated using historical data on the early releases and also from recent measurements by the Savannah River Ecology Laboratory (SREL), operated by the University of Georgia. ${ }^{5}$ The present inventories were obtained from area integrals of the contour data of (Fig. 5), and these confirm the other estimates, as shown in Table 2.

Table 2

Comparison of ${ }^{137} \mathrm{Cs}$ estimates in sediments of SRS ponds

\begin{tabular}{llll}
\hline & & & \\
& & & \\
& & \\
& & \\
Pond & Cs estimated in sediment, GBq \\
\cline { 2 - 4 } & Historical & SREL & Present \\
\hline Par Pond & $1300-2200$ & $\sim 1600$ & $1720 \pm 270$ \\
Pond C & $70-260$ & $\sim 130$ & $148 \pm 26$ \\
\hline
\end{tabular}

Subsequently, these results have been used to infer the ${ }^{137} \mathrm{Cs}$ in the floodplain of the creek below Par Pond Dam, ${ }^{5}$ to assist with site evaluations for any future changes in the pond levels, and to help screen and scope the extent of sediment contamination for the exposed areas.

The author thanks F.W. Whicker (SREL), S. Sundaram (Vogtle), and D.W. Hayes (SRS) for their technical input concerning this study. Information contained in the study was developed during the course of work done under Contract No. DE-AC09-89SR18035 with the U.S. Department of Energy. 


\section{References}

1. W.H. CARLTON, L.R. BAUER, A.G. EVANS, L.A. GEARY, C.E. MURPHY, JR., JE. PINDER, R.N. STORM, Report WSRC-RP-92-250, Westinghouse Savannah River Co, 1992.

2. W.G. WINN, W.W. BOWMAN, A.L. BONI, Sci. of Tot. Envir. 69 (1988), 107.

3. W.G. WINN, S. SUNDARAM, ANS Proc. Enviro. Trans. and Do'sim., ISBN: 0-89448-188-6 (1993), 101.

4. W.G. WINN, Report WSRC-TR-90-245, Westinghouse Savannah River Company, 1991.

5. W.G. WINN, Report WSRC-TR-93-0209, Westinghouse Savananah River Company, 1993.

6. W.G. WINN, Trans. Am. Nuc. Soc. 66 (1992), 32. 7.. F.W. WHICKER, J.E. PINDER, J.W. BOWLING, J.J. ALBERTS, I.L. BRISBIN, JR., Ecological
Monographs 60 (1990), 471. 